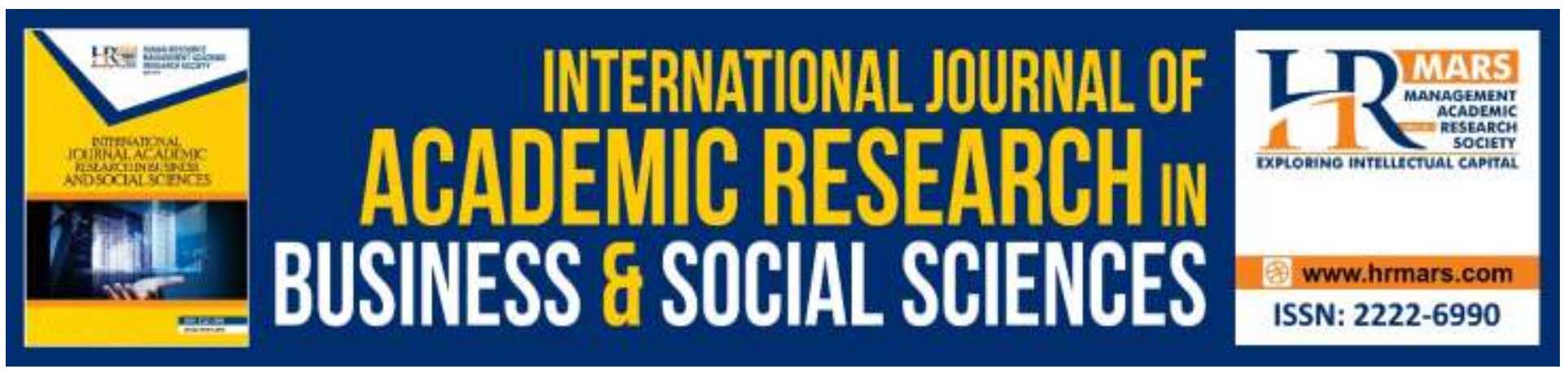

\title{
Impact of Microfinance Scheme towards Quality of Life Amongst the Rural Dweller's in Abia State of Nigeria
}

Valentine Umeh, Asnarulkhadi Abu Samah and Dahlia Zawawi

To Link this Article: http://dx.doi.org/10.6007/IJARBSS/v10-i4/7119

DOI:10.6007/IJARBSS/v10-i4/7119

Received: 21 February 2020, Revised: 16 March 2020, Accepted: 26 March 2020

Published Online: 14 April 2020

In-Text Citation: (Umeh et al., 2020)

To Cite this Article: Umeh, V., Samah, A. A., \& Zawawi, D. (2020). Impact of Microfinance Scheme Towards Quality of Life Amongst the Rural Dweller's in Abia State of Nigeria. International Journal of Academic Research in Business and Social Sciences, 10(4), 183-200.

Copyright: @ 2020 The Author(s)

Published by Human Resource Management Academic Research Society (www.hrmars.com)

This article is published under the Creative Commons Attribution (CC BY 4.0) license. Anyone may reproduce, distribute, translate and create derivative works of this article (for both commercial and non-commercial purposes), subject to full attribution to the original publication and authors. The full terms of this license may be seen

at: http://creativecommons.org/licences/by/4.0/legalcode

Vol. 10, No. 4, 2020, Pg. 183 - 200

http://hrmars.com/index.php/pages/detail/IJARBSS

JOURNAL HOMEPAGE

Full Terms \& Conditions of access and use can be found at http://hrmars.com/index.php/pages/detail/publication-ethics 


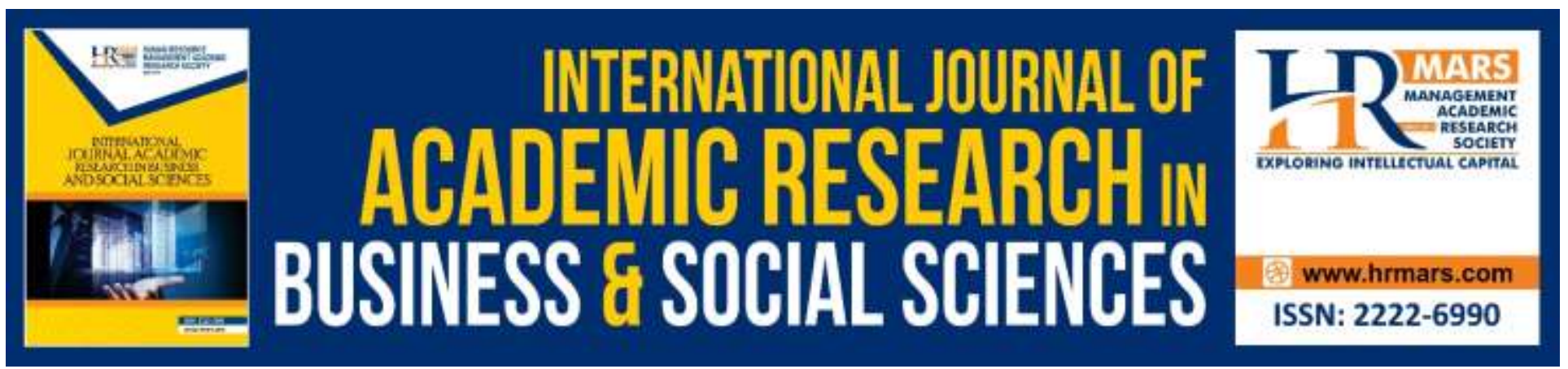

\title{
Impact of Microfinance Scheme Towards Quality of Life Amongst the Rural Dweller's in Abia State of Nigeria
}

\author{
${ }^{1}$ Valentine Umeh, ${ }^{1,2}$ Asnarulkhadi Abu Samah and ${ }^{3}$ Dahlia Zawawi \\ ${ }^{1}$ Institute for Social Science Studies, Universiti Putra Malaysia, ${ }^{2}$ Faculty of Human Ecology, \\ Universiti Putra Malaysia, ${ }^{3}$ Faculty of Economics and Management, Universiti Putra Malaysia \\ Email: asnarulhadi@gmail.com
}

\begin{abstract}
Poverty is a global and multi-dimensional issue that affect community's life. Poverty in its most general sense is the lack of necessities, basic food, shelter, medical care, and safety which influence the quality of life. Quality of life is a complex concept that incorporates many aspects of life, both material and non-material. Like many developing countries, in Nigeria, microfinance scheme plays a great role in improving the quality of life of its beneficiaries. This study is to examine the impact of microfinance scheme towards quality of life amongst the rural dwellers in Abia State of Nigeria. Specifically, this study examined the level of attitude, subjective norms, participation and quality of life among microfinance beneficiaries. This study also measured the mediating effect of participation on the relationship between attitude and subjective norm and quality of life. Simple stratified random sampling was used to select 391 respondents. The study covers all the 17 local government area of Abia State residents. Data was collected using developed questionnaires based on literature, concepts and related theory. The instruments were designed with 5 Likert scale and consists of five sections namely: the respondent's profile, attitude, subjective norm, participation and quality of life. Descriptive and inferential statistic such as Pearson correlation, and multiple regression was utilized to measure the relationship between the variables studied. The findings showed that there is a significant relationship between attitude, subjective norms, participation and quality of life. Findings also revealed that there is a mediating effect of participation between attitude and quality of life. Similarly, analysis also revealed that there is a mediating effect of participation between subjective norms and quality of life. This means that participation in microfinance scheme has strong impact towards improving the quality of life for the rural dwellers in Abia State of Nigeria. This study also indicates that microfinance scheme initiated by the government is a tool for rural community development. As such, this initiative, as a form of economic community development, has the potential to be implemented on a wider scale to improve the life of the rural community in Nigeria.
\end{abstract}

Keywords: Community Rural Development, Quality of Life, Participation, Microfinance Scheme. 
INTERNATIONAL JOURNAL OF ACADEMIC RESEARCH IN BUSINESS AND SOCIAL SCIENCES Vol. 10, No. 4, April, 2020, E-ISSN: 2222-6990 @ 2020 HRMARS

\section{Introduction}

Enhancement of quality of life has been their most priority towards enhancing the urban and rural development of Nigeria government. The dismal performance of the conventional finance sectors triggered the advocation of microfinancing by policy makers, practitioners, and international organizations as a tool for poverty reduction. Microfinance is a term used to describe the provision of financial services such as; savings, insurance and issuing loans (Olojede et al., 2013). According to Ghani (2017) defined microfinancing as the delivery of financial services to poor and low-income households with limited access to formal financial institutions. However, it would also be described as banking for the underprivileged (Hewitt et al., 2018). According to Phillips (2006) defined quality of life as a multifaceted phenomenon that focuses on promoting various aspect of life such as; good health, housing, safety, financial capability and adequate education effectively. The microfinance scheme in Nigeria has been operated since in 1940s and its started in the eastern part of Nigeria under the colonial officers with an anthropological background recommended the transformation of osusu or isusu (the Igbo term) to financial cooperatives as well as the continuation of isusu practices within modern cooperatives (Giwa et al., 2017). The Nigerian microfinance industry has come a long way. It boasts of the entire four well - known models in the industry. A CBN study in 2010 identified that there are 213 registered Microfinance Institutions (MFIs) in Nigeria with aggregate savings worth N99.4 million and outstanding credit of N649.6 million, indicating huge business transactions in the sector (Nwanyanwu, 2011). With a population of about 180 million and GDP per capita of $\$ 641$ (2017), two - thirds of Nigeria's people are poor. A study conducted in 2018 by the CBN identified that 652 registered microfinance institution in Nigeria and while 38 are registered in Abia State for the purpose of promoting quality of life (CBN, 2018). The creation of Microfinance banks was to enhance access of loans and savings services for the underprivileged and this is presently being encouraged as an essential development strategy to facilitate poverty eradication in Nigeria (Oyedepo, 2018). In the past, Abia State of Nigeria Government has initiated series of micro programmes targeted at the poor with the objectives of making credit readily available to those who were traditionally denied access to credit (Hilson et al., 2018). The role of microfinance was to promote quality of life of the residents as stated below; providing loan access to the poor, prohibit the exploitation of the poor by money-lenders, creating opportunities for self-employment for the unemployed, and end the vicious circle of "low income, saving \& investment", and by creating a virtuous circle of "injection of credit for investments of rural dweller for more income, savings, and investment respectively".

Globally, poverty has been an issue affecting most African Countries. Nigeria is faced with high level of poverty that affect their citizens. Poverty is a curial issue that affects the Abia State of Nigeria. Poverty is defined as the state of being inferior in quality or insufficient in amount (Galadima, 2014). Furthermore, poverty is the scarcity or the lack of a certain (variant) amount of material possession or money. He further proved that poverty is a multifaceted concept, which may include social, economic, and political elements. However, the threshold at which relative poverty is defined varies from country to another, or from one society to another (Othman, 2015). In addition, this issue hinders that continuous growth of quality of life in Nigeria. Microfinance scheme have diverse various strategies on how to reduce and minimize the poverty rate by empowering the rural dwellers with credits, loan and business opportunities to growth in their respective business for the betterment of 
quality of life. Quality of life of rural dwellers in Abia is been tramped up as part of low awareness by the microfinance institutions to empower the residents of Abia State of Nigeria. The low awareness could be deduced as a result of low financing by the government. Rural dweller experienced challenges that hinders their participation in microfinance scheme to better their lives such as; lack of beliefs, uncertain results to be expected, low motivation to comply, lack of decision making, implementation process and monitoring process are in doubts and these leads to poor participation as well as quality of life (Galadima, 2014; Jan, 2018). However, adequate awareness by the microfinance scheme and its benefits will upturn these hindrances effectively (Shaaban \& Petinrin, 2017). These challenges have leads to great effects on quality of life of the rural dwellers in Abia State of Nigeria and these effects as follows; poor access to roads, poor educational facilities, lack of portable water, low per capita income, high unemployment and inadequate power supply. Warsame \& Ireri (2018) argued that rural communities are usually characterized by poor healthcare, lack of basic nutrition, and inadequate housing.

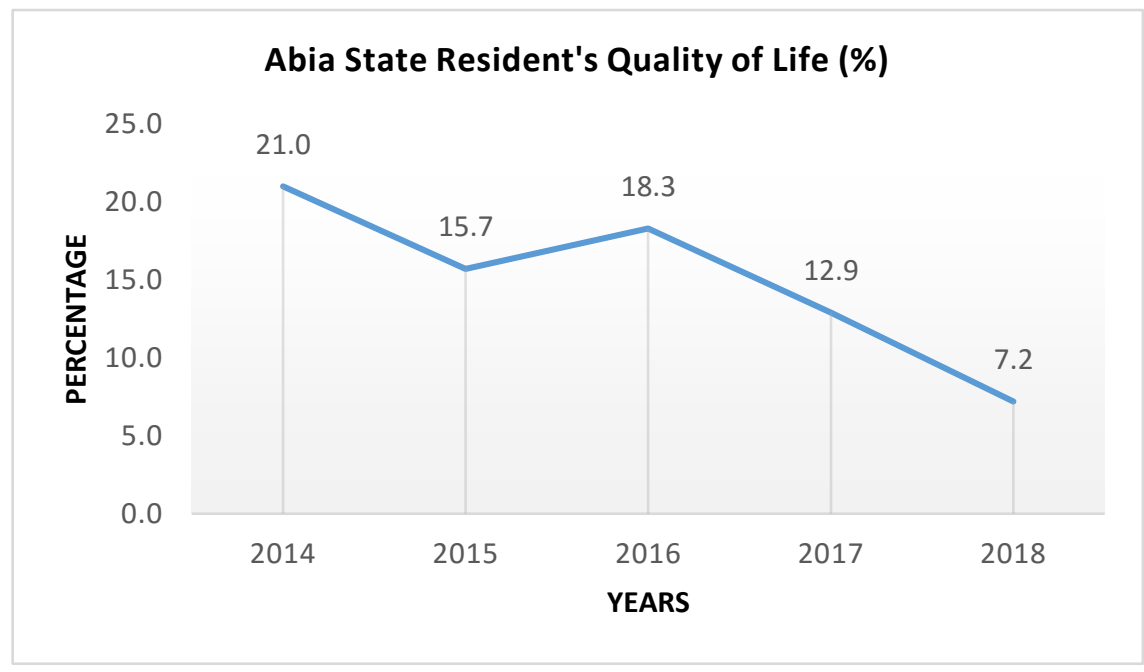

Figure 1.1: The Central Bank of Nigeria in 2018 (CBN, 2018).

Figure 1.1 confirmed that the resident's quality of life in Abia State of Nigeria are gradually reducing and which was as a result of poverty within the state. Microfinance scheme need to provide an enabling environment for the rural dweller's participation to better their lives. However, over 2 million populations (out of $3,727,300$ ) [56.8\%] of Abia state resident's faces low quality of life as a result poverty (CBN, 2018). From the analysis, it proved that the identified causes of poor quality of life in Abia State of Nigeria are as follows; low income, poor health, unsafe environment, poor education, poor housing, and infrastructure and these promotes low quality of life for the Abia state resident (CBN, 2018). Lahkar \& Pingali (2016) agreed that most communities are known for their poor quality of life as a result of poor roads, poor water amenities and poor power supply and these issues drastically affect the rural dwellers. However, these issues lead to this study objectives, and which focused as follows;

(1) to determine the relationship between attitude, subjective norms, participation and quality of life.

(2) to determine the mediating effect of participation on the association between attitude and quality of life. 
INTERNATIONAL JOURNAL OF ACADEMIC RESEARCH IN BUSINESS AND SOCIAL SCIENCES Vol. 10, No. 4, April, 2020, E-ISSN: 2222-6990 @ 2020 HRMARS

(3) to identify the mediating effect of participation on the association between subjective norm and quality of life.

\section{Literature Review \\ Quality of Life}

Quality of life is the general well-being of individuals and societies, outlining negative and positive features of life (Phillips, 2006). It observes life satisfaction, including everything including; physical health, family, education, employment, wealth, safety, security to freedom, religious beliefs, and the environment. According to Banki and Ismail (2015) argued that quality of life is a highly subjective measure of happiness that is an important component of many financial decisions. Yimga (2018) argued that microfinance scheme has aided most communities towards reducing the poverty and provide several opportunities for self-development and capability growth. However, the level of participation of communities depends on their attitude and subjective norm toward promoting quality of life. The higher the level of participation of microfinance scheme, the higher they tend to obtain good quality of life. Rita et al., (2012) agreed that the higher the level of participation, the higher the level of decision and implementation process towards promoting quality of life. Attitude and subjective norms of the rural dwellers plays a key role in achieving the quality of life they desired. Financial decisions by microfinance usually involve a trade-off, where quality of life is decreased, in order to save money or, conversely, quality of life is increased by spending more money (Yi-ping et al., 2016). Awojobi (2014) disagreed that quality of life is an issue when developing a personal savings plan. In this study, the trade-off involves a sacrifice of current quality of life, in order to improve future quality of life. This may include limiting immediate expenditures by purchasing lower cost items rather than buying higher cost of premium items (Nwanyanwu, 2011). According to Gregory (2012) affirmed that quality of life focuses on the values. Furthermore, quality of life plays significant role in promoting individual goals, aspiration and needs, and which are considered vital tools towards the individual fulfilment in life. According to the World Bank (2017) agreed that the indicators implemented to examine and evaluate the level of quality of life are related to health, earnings, safety, employment and education. Poverty, unemployment and low quality of life would be used to determine quality of life of a population (World Development Indicators, 2017). Individual perceived the level of satisfaction from various contributions deduced from quality of life. However, those contributions of quality of life are stated below; good environment, good health, improved education, opportunities of business for financial income and good housing for individual satisfaction. These factors of contribution were relevant to the development of quality of life by various studies. The betterment of these values and satisfaction would enhance the livelihood of rural dwellers as well as promote the quality of life effectively. The constructs of quality of life as follows;

\section{Education}

Education is perceived as one of the most significant factors of quality and which deals on individual capability to understand and improve the skills, in order to enhance the quality of life effectively. In the Ekiti State of Nigeria, there are huge showcase of low literate rate and which affect the rural dwellers in participating in microfinance scheme and to get involved in things that would be beneficiary towards promoting quality of life. The respondents of the study in Ekiti State perceived 
that there are many people that did not go to school and which affect their level of reasoning on the ways to promote the livelihood of the community. However, Nigeria vision 2020 was to promote and encourage education in all level and all part of Nigeria and which would help to improve the individual involvement in daily activities such as; business, trade etc. Education is the key of economic growth in any country (Okoye et al., 2016). Furthermore, education would help the rural dweller's in pursuit or access of information that would help to promote the basic skills needed to be successful in the rural area. The adaptation of basic skills by the rural dweller, would help to create more opportunities and which would reflect positively to the economic development of Abia State.

\section{Housing}

Adequate housing is a necessity of life and which was perceived as the most vital instrument to ascertain individual quality of life. According to Janina et al., (2018) affirmed that most individuals stay in the rural area in Abia state are not comfortable and those areas are not suitable to live in. However, housing is considered as a key factor for individual fulfilment in life. Men and women have the equal right to a decent housing and adequate quality of life in Nigeria (Nadine, 2018). Housing help individual in fulfilling the physical basic needs of securing shelter and security from the harmful climate and weather effectively. Housing provide individual the sense of privacy, personal space, and social fulfilled, and which help to promote the quality of life they tend to attain in life. Housing could be used for community gathering, social peer group meeting and family space respectively. Getting access of information of microfinance scheme such as; access credits and managing savings would provide rural dweller's the opportunities to generate funds that would be used to own a house of their choice (Eva, 2017).

\section{Income}

Income is an essential factor of life. Without income, individual would not able to survive in the long term. From the perceptive of rural dweller's, income generating is the key for promoting of quality of life and to sustain the livelihood. However, Nigeria has a minimum wage of \#7,500 Naira that was introduced in 1999. In 2015, the minimum wage of an employee in Nigeria is \#18, 000 Naira and which is relatively low compared to other countries, and which reduce the quality of life of the dwellers. This new minimum wage trigger inflation rate in Nigeria and make the rural dweller inability to survive effectively. A study shown that poverty is a crucial issue that faced rural area globally (Carol et al., 2014). Many rural dwellers operate in a low-income level, and which made them not been able to operate a bank, in order to create saving for future life. According to Awojobi (2014) agreed that poor income earners are the individual staying in the rural area. There is a need for rural dweller to emphasis to invest in activities that required little amount of money as investment. Furthermore, it is essential for rural dweller to access the microfinance scheme information as it would boost their level of income, if they participated effectively in the scheme and which would reflect towards enhancing their quality of life.

\section{Safety}

Safety is essential for rural dweller and community development. Quality of life in the rural area also emphasised on the level of safety minted to the rural dwellers. Any community that does not have adequate safety, the residents tends to live a life of fears and which would result to poor security and 
INTERNATIONAL JOURNAL OF ACADEMIC RESEARCH IN BUSINESS AND SOCIAL SCIENCES Vol. 10, No. 4, April, 2020, E-ISSN: 2222-6990 @ 2020 HRMARS

unsafe. For individual to established quality of life, safety needs to be fulfilled effectively (Galadima, 2014). Adequate neighbourhood is perceived as areas with space dimensions, clean environment, low crime area, interactive people and democratic ways of life. These would affect the individual positively on the level of satisfaction and expectation in fulfilment of quality of life. According to Ebhuoma \& Simatele, (2017) conducted a study on Ekiti State with regards to neighbourhood and which proved that the rural dweller perceived their areas as unsafety and threatened their existence of life. Some of the respondents also indicated that the areas have high crime rate and filled with corrupt people as Ekiti State experienced political instability. Participating in the microfinance scheme would provide the rural dwellers the opportunities in term of access credit for business to generate income to secure a safety place for living and business operation. According to Emenike et al., (2014) asserted that the access of information from microfinance scheme would promote the rural dweller's quality of life, and which would promote the access to adequate water supply, securing electricity and abolition of poverty within the neighbourhood.

\section{Health}

According to Gregor et al., (2017) affirmed that health is wealth. The State of health and expectation of individual lies in the sense of enhanced quality of life. Health deals on the mental and physical satisfaction and not just the absence of diseases. The health status has been used as an indicator to determine the level of healthy people in the community. A study conducted by Okwoli et al., (2013) affirmed that people that exhibits good health feed quality nourishment and which reflected to the development of their body. Most of the rural dweller's feeds on their farm products, which has been perceived as freshness and richness towards the nourishment of the body (Asadul, 2015). However, the access and use of information gained from microfinance scheme would prevent indiscriminate use of drugs among rural dwellers. This would help to prevent terminal and incurable diseases within the community. Information about health and diseases are crucial and they are stationed in areas such as; handbills, internet, books and newspapers that cannot be reached by the rural dwellers. By participating in the microfinance scheme, such information about diseases and health would be made available to the dwellers and which would help to reduce the spreading of the diseases effectively.

\section{Participation}

Participation is a dynamic process (Cagliero et al., 2011). It is also difficult to predict or even to quantify using a standard 'measurement'. Samer et al., (2015) argued that participation: 'a social process whereby specific groups with shared needs living in a defined geographic area actively pursue identification of their needs, take decisions and establish mechanisms to meet these needs'. Toyobo et al., (2015) argued that decision-making is defined as 'involvement of the local population actively in the decision-making concerning development projects or in their implementation. Rural participation is about the ways in which rural dwellers exercise influence and have control over the decisions that affect them' (Siti et al., 2015). Finally, Eva, (2017) agreed that participation is a range of processes through which local communities are involved and play a role in issues which affect them. The extent to which power is shared in decision-making varies according to type of participation'. According to the theory of rural development participation by Cohen and Uphoff (1980) defined participation "as people's involvement in decision making process about what would be done and how it is done; their involvement in implementing programs and decision by 
contributing various resources and cooperating in specific organizations or activities; their sharing in the benefits of development programs; and their involvement in efforts to evaluate the microfinance scheme effectively. Participation simply means collective and continuous efforts by rural dweller's themselves in setting goals, pooling resources together and taking actions which aim at improving their quality of life (Ezeala-Adikaibe et al., 2018). Moreover, participation has been conceptualized as representative of partnership and ownership from the 'bottom-up' perspective (Nkemngu, 2015; René \& Mirek, 2014), with involvement of people in decision making processes, implementing programs, sharing the benefits of development programs and their involvement in efforts to evaluate microfinance programs (Cohen \& Uphoff, 1980). By promoting community participation in such programs, rural dwellers would gain more local control and greater influence over their community resources (Cohen \& Uphoff, 1980). Therefore, community development programs can only succeed, if the people in the target area participate in the planning, decision making, implementation and evaluation of this program (Zubairu, 2017).

The mediating effect of participation for rural dweller towards promoting quality was successfully promoted with the aid of attitude, subjective and its dimensions. For rural development concepts, participation would be able to promote the quality of life of rural dweller effectively upon a high level of expected outcome of their involvement (Tchuigoua, 2018). Attitude plays an important role for effective participation and which in turn yield a desirable quality of life (Ikurekong \& Atser, 2013). Rural dwellers are faced with family pressure, financial constraints, friends and peer pressure which trigger's them to participate in microfinance scheme. From the rural dweller's perspective, he or she needs to fulfil the necessities of life, and which would trigger them to participate towards achieving quality of life for their families (Nkemngu, 2015; Carol Holtz et al., 2014). Subjective norm has a strong role in persuading someone to get involved in the actualising a desirable solution to their problem (Fan, 2014). Poverty has been an issue in rural communities, by participation of microfinance scheme due to the pressure from the family, the dweller would be able to provide for the family at the same improve the quality of life effectively (Akpan \& Nneji, 2015). Researchers opined that rural dweller's participation is influenced by the evaluation of expected outcome from those who have participated in the microfinance scheme, and which would build trust and enable their participation effectively (Torres \& Zeidan, 2016; Mohammed \& Edward, 2018; Taramol, 2015). According to Yimga (2018); Warsame \& Ireri (2018) proved that trust was found to have a significant positive impact on the attitude towards promoting quality of life upon effective participation of the microfinance scheme. It also expected that outcome has positively influence on the rural dweller attitude towards participation. Okwoli et al., (2013) showed that attitude is one of the significant factors that influence the dweller's participation for the betterment of their quality of life. The effect of participation helps to promote the rural dweller's quality of life. The dimensions of participation such as; planning/decision making, implementation, and monitoring and evaluating processes has severally aided the rural dweller in microfinance scheme and which in turn promote their quality of life.

\section{Attitude}

According to Ashamu (2014) agreed that the individual evaluation of behaviour is known as attitude. These concepts further elaborate the two dimension that help the individual to understand extensively on how well to evaluate their beliefs and outcome sequentially. The belief and evaluation 
of outcome was the two dimension of attitude and which was useful to determine the rural dweller's belief about the microfinance scheme and their expected evaluation outcome, in order to boost their continuously participation towards enhancing quality of life. According to the TRA, stipulated that attitude is considered as a learning activity that could be negative or positive results based on the individual action (Ajzen, 1999). Two components of one's attitude towards a certain behaviour are the belief strengths and past exposures (Ajzen, 1991). The beliefs are based on simple true or false responses. These evaluations involve the values or "judgments of worth" one has placed on a certain position (Benoit 2008). A variety of factors would influenced the attitude-behaviour relationship, including "such aspects as confidence in one's attitudes, involvement with the attitude object, it's centrality or importance, attitudinal ambivalence, the attitude's accessibility in memory and its temporal stability" (Murshid \& Ely, 2016). These authors suggested that attitude strength is an important moderating factor, and that strong attitudes do predict behaviour better than weak attitudes, although this may not always be the case.

\section{Subjective Norm}

Subjective norm deals on the individual beliefs and expectation of other people (Ajzen, 1999). These subjective norms dealt with what one thinks as well as how one is motivated (Ajzen, 1999). This also included how influential a peer can be in each situation (Fortier et al., 1995). When an individual was faced with normative belief, it would be easier to succumb to social pressure. It believed that social norms of someone could be determined by persuasive thought of an individual. However, research have argued that the determinant of individual's behaviour was based on their subjective norm and attitude. In the other word, the both concepts intersect with each individual behavioural intent (Tibesigwa \& Visser, 2016). People's health decisions are often influenced by how they view the actions they are considering as well as by the impact others have on their motives (Murshid \& Ely, 2016). So, attitudes and social norms must jointly work together to produce a behavioural intention (quality of life) as the dependent variable. An example of this includes the HCP having a positive attitude about hospice services based on past beliefs or even the experiences of colleagues. 


\section{Conceptual Framework}

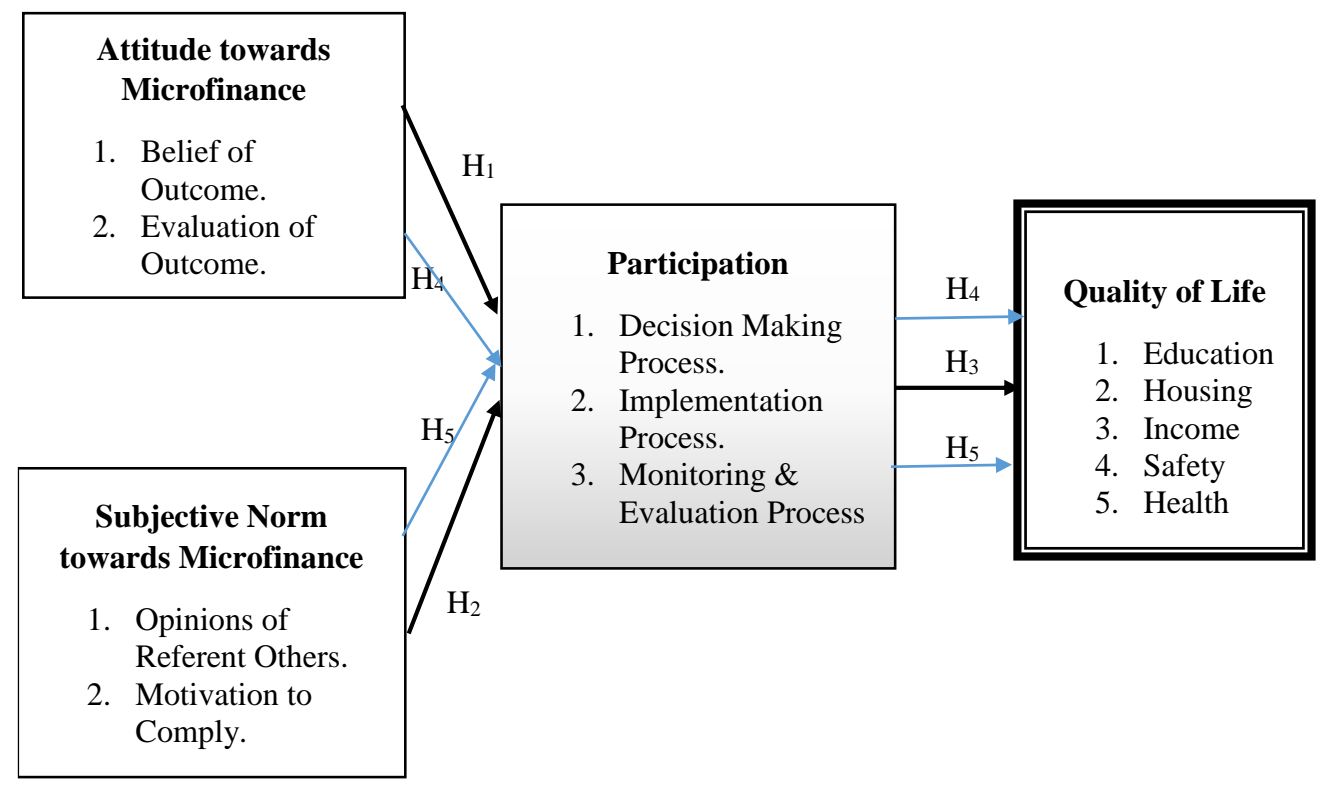

Figure 2.1: Conceptual Framework of this Study

\section{Methodology}

This study applied self-administered survey. Since this study involved rural dwellers in Abia State of Nigeria as the respondents, approvals from a few microfinance institutions were obtained and the respective microfinance institutions were sought prior to distributing the questionnaires. However, the questionnaires were distributed among three (3) communities in each 17 local government area of Abia State of Nigeria. Simple and stratified sampling were adopted for the distribution and collection of data from the respondents within the aged range of 18-65 years respectively.

\section{Sampling}

This study focused only rural dwellers of Abia State of Nigeria. According to Krejcie and Morgan (1970) affirmed that at 5\% margin of error with 95\% confidence interval, the 391 respondents was adopted as the sample size of this study.

\section{Measurements}

The measurement of quality of life have been reviewed by various authors on the quality of life scales, and the researcher chooses the most cited index and which was extracted from Ventegodt et al., (2003), Deaton (2008), Müller et al., (2005), Diener et al., (1995), Bigelow et al., (1991). The quality of life has five (5) dimensions that was identified by the aid of Theory of Reasoned Action (Ajzen, 1999), Quality of life theory (Ventegodt et al., 2003), and Maslow's hierarchy of needs (Maslow, 1962) and which focuses on the following dimensions; Education, Housing, Income, Safety, and Health. The participation was adopted mediating variable for this study and after reviewing an array of participation scales, the researcher chooses the most cited level of participation index and which was extracted from Disalvo et. al (2012), Haski-Leventhal (2013) and Spinney et al., (1992). Participation 
INTERNATIONAL JOURNAL OF ACADEMIC RESEARCH IN BUSINESS AND SOCIAL SCIENCES Vol. 10, No. 4, April, 2020, E-ISSN: 2222-6990 @ 2020 HRMARS

has three (3) dimensions that was identified by the aid of Participation theory by Cohen and Uphooff (1980) and which focuses on; decision making process, implementation process, and monitoring and evaluating process respectively. The purpose of measuring Attitude and after reviewing an array of attitude scales, the researcher chooses the most cited attitude index and which was extracted from Murdie at al., (1992), Flora et. al., (1992) and Jon (2000). Lastly, subjective norm was reviewed by various array of subjective norm scales, the researcher chooses the most cited index, and which was extracted from Christenson \& Robinson (1989), Sanders (1958), Welsch \& Kuhns, (2002). These variables were analysed based on the five (5) Likert scales, to examine the impact of the rural dweller's attitude towards promoting the quality of life.

\section{Findings and Discussions}

A total of 450 questionnaires were distributed and 391 (86.89\%) were returned. However, out of the total questionnaires distributed, only 59 questionnaires were incomplete.

\section{Demographic Profile}

The respondents aged were 18 - 24 years have $16.6 \%$ (65 respondents), $25-30$ years have $30.7 \%$ (120 respondents), 31 - 36 years has $34.5 \%$ (135 respondents) and lastly, 37 years and above have 18.2\% (71 respondents). Male and female respondents were involved in this study and the rate of Male respondents was $42.7 \%$ (167 respondent's) female was $57.3 \%$ (224 respondents). The tribe of Igbo had $81.4 \%$ (319 respondents), Hausa had 7.9\% (31 respondents), Yoruba had 8.2\% (32 respondents) and other tribes such as; Efik, Tiv etc had 2.3\% (9 respondents) respectively. The level of education amongst the respondents was considered low as they do not have much education background to manage their day to day business operation. No basic education has $14.6 \%$ (57 respondents), primary school had 37.3\% (146 respondents), secondary school had 28.9\% (113 respondents), national diploma had 9.0\% (35 respondents), higher national diploma had 6.1\% (24 respondents), and bachelor degree had $4.1 \%$ (16 respondents). With regards to the income of the respondents, it showed that \#1,000 - \#20,000 had 33.5\% (132 respondents), \#21,000 - \#40,000 had 38.6\% (151 respondents), \#41,000 - \#60,000 had $18.7 \%$ (73 respondents) and finally, \#61,000 and above had 9.0\% (35 respondents). From the occupation aspect, it proved that Abia state rural dweller are known for trader, and which does not require advance education to manage. The trader had 64.2\% (251 respondents), farmer had $14.6 \%$ (57 respondents) and others had $21.2 \%$ (83 respondents) were involved in this study.

\section{Hypotheses Testing (Correlation)}

Pearson Correlation was used to determine the relationship between two or more variable in identify the dependent variable. In this study, the analysis was to determine the relationship between attitude, subjective norm, and participation towards quality of life respectively. Though, this was deployed to analyse the objective 1 and which has three (3) hypothesis $\mathrm{H}_{1}, \mathrm{H}_{2}$ and $\mathrm{H}_{3}$ stated below;

$\mathrm{H}_{1}$ : There is a relationship between the attitude and participation.

$\mathrm{H}_{2}$ : There is a relationship between the subjective norm and participation.

$\mathrm{H}_{3}$ : There is a relationship between the participation and quality of life. 
INTERNATIONAL JOURNAL OF ACADEMIC RESEARCH IN BUSINESS AND SOCIAL SCIENCES

Vol. 10, No. 4, April, 2020, E-ISSN: 2222-6990 @ 2020 HRMARS

Table 4.1: Correlations between Quality of Life, Participation, Attitude and Subjective Norm

\begin{tabular}{lllll}
\hline & Quality of Life & Participation & Attitude & Subjective Norm \\
\hline Quality of Life & 1 & & & \\
Participation & $0.806^{* *}$ & 1 & & \\
Attitude & $0.885^{* *}$ & $0.701^{* *}$ & 1 & \\
Subjective Norm & $0.945^{* *}$ & $0.717^{* *}$ & $0.910^{* *}$ & 1 \\
\hline
\end{tabular}

Note: ${ }^{* *}$ significant level at $\mathrm{p}<0.01$

Table 4.1 showed that the relationship between the attitude, subjective norm, participation and quality of life. In order to justify the hypothesis 1 , the attitude had ( $r=0.701, p<0.01$ ), subjective norm had $(r=0.717, p<0.01)$ and participation $(r=0.806, p<0.01)$ respectively. This further affirmed that there is a relationship between attitude, subjective norm, and participation towards promoting resident's quality of life. In addition, it agreed that the attitude and subjective norm of residents toward microfinance scheme had strong correlation with level of participation for the betterment of quality of life. Therefore, the research objective 2 was successfully achieved and accept $\mathrm{H}_{1}, \mathrm{H}_{2}$ and $\mathrm{H}_{3}$.

\section{Hypotheses Testing (Regression)}

The regression analysis was used to determine the mediating effect of participation between the attitude and subjective norms towards quality of life as the dependent variable. For regression to be accepted, the $R^{2}$ value of 0.71 and above of any independent variable explained a lot of variability, and while 0.30 to 0.70 explained moderate variability respectively. Though, multiple regression was used to determine the objective 2 and 3 , and which focused on the hypothesis $\mathrm{H}_{4}$ and $\mathrm{H}_{5}$ that was highlighted in table 4.2 and 4.3 respectively.

Table 4.2: Regression Coefficients for Mediating Effect of Participation between Attitude and Quality of Life

\begin{tabular}{|c|c|c|c|c|c|c|c|}
\hline \multirow[t]{2}{*}{ Model } & \multirow{2}{*}{\begin{tabular}{|l} 
Standardiz \\
ed \\
Coefficient \\
S
\end{tabular}} & \multirow[t]{2}{*}{$t$} & \multirow[t]{2}{*}{ Sig. } & \multicolumn{2}{|c|}{$\begin{array}{l}\text { Model } \\
\text { Summar } \\
\text { y }\end{array}$} & \multicolumn{2}{|c|}{$\begin{array}{l}\text { Analysis } \\
\text { Variance }\end{array}$} \\
\hline & & & & $\mathbf{R}$ & $\mathbf{R}^{2}$ & $\mathbf{F}$ & Sig. \\
\hline (Constant) & & 7.420 & .000 & $\begin{array}{l}.87 \\
6\end{array}$ & $\begin{array}{l}.76 \\
8\end{array}$ & 642.878 & .000 \\
\hline 1 Attitude & -.739 & & .000 & & & & \\
\hline $\begin{array}{l}\text { Quality of } \\
\text { Life }\end{array}$ & 1.460 & 27.824 & .000 & & & & \\
\hline
\end{tabular}

a. Dependent Variable: Participation

Table 4.2 showed the mediating effect of participation on the association between attitude and quality of life. 
INTERNATIONAL JOURNAL OF ACADEMIC RESEARCH IN BUSINESS AND SOCIAL SCIENCES

Vol. 10, No. 4, April, 2020, E-ISSN: 2222-6990 @ 2020 HRMARS

$\mathrm{H}_{4}$ : There is a mediating effect of participation on the association between attitude and quality of life.

Table 4.2 showed that the model was considered good with adjusted $R^{2}$ at 0.768 indicating that a high $76.8 \%$ of the variability in participation has been explained by Attitude and Quality of life (Rumsey, 2009). However, the table also proved that $F$ value was significant at $F(2,388)=642.878$, $p<0.001$. Finally, attitude and quality of life was significant to the participation as the dependent variable. It further highlighted that beta of attitude was -0.739 , quality of life was 1.460 and $p<0.001$. Therefore, the research objective 3 was successfully achieved and accept $\mathrm{H}_{4}$

Table 4.3: Regression Coefficients for Mediating Effect of Participation between Subjective Norm and Quality of Life

\begin{tabular}{|c|c|c|c|c|c|c|c|}
\hline \multirow[t]{2}{*}{ Model } & \multirow{2}{*}{\begin{tabular}{|l} 
Standardiz \\
ed \\
Coefficient \\
S \\
Beta
\end{tabular}} & \multirow[t]{2}{*}{$t$} & \multirow[t]{2}{*}{ Sig. } & \multicolumn{2}{|c|}{$\begin{array}{l}\text { Model } \\
\text { Summar } \\
\text { y }\end{array}$} & \multicolumn{2}{|c|}{$\begin{array}{l}\text { Analysis of } \\
\text { Variance }\end{array}$} \\
\hline & & & & $\mathbf{R}$ & $\mathbf{R}^{2}$ & $F$ & Sig. \\
\hline (Constant) & & 4.109 & .000 & $\begin{array}{l}.81 \\
7\end{array}$ & $\begin{array}{l}.70 \\
6\end{array}$ & 389.279 & .000 \\
\hline 1 Subjective & -.406 & -4.554 & .000 & & & & \\
\hline $\begin{array}{l}\text { Quality of } \\
\text { Life }\end{array}$ & 1.189 & $\begin{array}{l}13.34 \\
2\end{array}$ & .000 & & & & \\
\hline
\end{tabular}

a. Dependent Variable: Participation

Table 4.3 showed the mediating effect of participation on the association between subjective norm and quality of life.

$\mathrm{H}_{5}$ : There is a mediating effect of participation on the association between subjective norm and quality of life.

Table 4.3 showed that the model was considered good with adjusted R2 at 0.706 indicating that a high $70.6 \%$ of the variability in participation has been explained by subjective norm and Quality of life (Corry et. al, 2009). However, the table also showed that $F$ value was significant at $F(2,388)=$ $389.279, p<0.001$. Finally, subjective norm and quality of life was significant to the participation as the dependent variable. It further highlighted that beta of attitude was -0.406, quality of life was 1.189 and $p<0.001$. Therefore, the research objective 4 was successfully achieved and accept $\mathrm{H}_{5}$.

\section{Conclusion}

This study has successfully achieved the four (4) objectives respectively. From these findings, the microfinance scheme proved that there is a low ability of belief in microfinance by the residents. This further, concluded that microfinance scheme needs to empower the participants towards have assurance in their scheme, to empower their growth opportunities and improved the wellbeing. The 
improvement of microfinance scheme awareness would contribute significantly towards rural dweller's participation and helps to promote their belief on the scheme's benefits. Motivation to comply and opinion of referent other has helped rural dweller toward participation as well as enhanced their quality of life. Furthermore, motivation to comply such as; business opportunities, improved wellbeing, and adapting with quality of life has been proved to be the reason behinds participants of microfinance scheme towards participating. Quality of life is crucial and essentials for both urban and rural dwellers of Nigeria. Participants was agreed to exercised decision making process and implementation process that triggered their mind-set for the involvement of microfinance scheme. This was successful yield a strong and significant impact towards quality of life. Attitude under evaluation has helped most residents in participating effectively and which have ascertained with the level of motivation to comply triggered their business expansion ideas towards getting involved in the scheme for the betterment of their standard of living as well as quality of life enhancement. This was crucial for the local government of Abia State and microfinance scheme institutions to create and sustained the reoccurrence of this programme with a proper implementation and solid support by the rural dwellers and the resident's complaints towards the level of quality of life and participation was gradually diminished. This effect was believed to be main driving force behind the stability and social growth provided by the local government area for their residents. Thus, this study was expected to produce main contributions within the scope of quality of life among the rural dweller.

\section{Recommendations for Future Research}

Since this study focused on microfinance scheme, it plays an important role in the Abia State rural dweller quality of life development. Comparative studies across other states of Nigeria should be conducted to determine the practices of microfinance scheme with regards to the followings; safety, road transport department, hospital, income generating offices, education for skill acquisition and good housing infrastructure, in order to boost the rural dweller's standard of living as well as increase the ability to generalize the research findings. Based on this study, the belief of the residents was not well supported on the ideas generated from the microfinance scheme as non-motivating factor. However, this would have been significant if the microfinance scheme officers be able to promote their awareness and hint on the scheme's benefits with a few resident's testimonies, this would help to enhance the assurance as well as their belief. Further, it would help to increase the level of motivation to comply by the residents effectively. However, education, housing, income, safety and health should be continuously implemented by the microfinance as they have strong and direct significant impact on the development of quality of life. It is highly recommended that an indigenous approach should be taken into action towards developing a new quality of life scales that incorporates Abia State cultural values that promote the rural dwellers. Hence, with the new development of the Abia State quality of life scale that is pertinent to Nigerian culture. These values can complement the scale developed by Hamed (2015) on subjective norm in Abia State Local government area. Thus, the true effect of willingness for the rural dweller in exhibiting Quality of life and its associations should be examined constructively and objectively in Abia State rural dweller's standard of living development strategies. 
INTERNATIONAL JOURNAL OF ACADEMIC RESEARCH IN BUSINESS AND SOCIAL SCIENCES Vol. 10, No. 4, April, 2020, E-ISSN: 2222-6990 @ 2020 HRMARS

\section{References}

Ajzen, I. (1991). The theory of planned behavior. Organizational behavior and human decision processes, 50(2), 179-211.

Ajzen, I. (1999). Dual-mode processing in the pursuit of insight is no vice. Psychological Inquiry, 10(2), 110-112.

Akpan, E. S., \& Nneji, I. D. (2015). Contribution of microfinance banks to the development of small and medium scale enterprises in Nigeria. Research Journal of Finance and Accounting, 6(8), 1928.

Ashamu, S. O. (2014). The impact of micro-finance on small scale business in Nigeria. Journal of Policy and Development Studies, 289(1849), 1-15.

Awojobi, O. N. (2014). Empowering women through micro-finance: Evidence from Nigeria. Australian Journal of Business and Management Research, 4(1), 17.

Banki, M. B., \& Ismail, H. N. (2015). Understanding the characteristics of family owned tourism micro businesses in mountain destinations in developing countries: evidence from Nigeria. Tourism Management Perspectives, 13, 18-32..

Bigelow, D. A., McFarland, B. H., \& Olson, M. M. (1991). Quality of life of community mental health program clients: Validating a measure. Community Mental Health Journal, 27(1), 43-55.

Cagliero R., Cristiano S., Pierangeli F., Tarangioli S. (2011). Evaluating the Improvement of Quality of Life in Rural Areas. Istituto Nazionale di Economia Agraria (INEA), Roma, Italy, 1(2), 17-18.

CBN. (2018). Central Bank of Nigeria Economic Report 2018. Microfinance Scheme Report. Poverty Alleviation Programme in Nigeria. published as at 31 ${ }^{\text {st }}$ December 2018.

Christenson, J. A., \& Robinson, J. W. (1989). Community development in perspective. Iowa State University Press.

Cohen, J., and Uphoff, N. (1980). Participation's place in rural development: Seeking clarity through specificity. World Development, 8(2), 213-235.

Corry, N., Pruzinsky, T., \& Rumsey, N. (2009). Quality of life and psychosocial adjustment to burn injury: Social functioning, body image, and health policy perspectives. International Review of Psychiatry, 21(6), 539-548.

Deaton, A. (2008). Income, health, and well-being around the world: Evidence from the Gallup World Poll. Journal of Economic perspectives, 22(2), 53-72.

Diener, E. (1995). A value based index for measuring national quality of life. Social indicators research, 36(2), 107-127.

DiSalvo, C., Clement, A., \& Pipek, V. (2012). Communities: Participatory Design for, with and by communities. In Routledge international handbook of participatory design (pp. 202-230). Routledge.

Ebhuoma, E., \& Simatele, D. (2017). Defying the odds: Climate variability, asset adaptation and food security nexus in the Delta State of Nigeria. International Journal of Disaster Risk Reduction, 21, 231-242.

Emenike, C. P. I. T., Tenebe, D. O., Omole, B. U., Ngene, B. I., Oniemayin, O., Maxwell, B. I. O. (2014). Accessing safe drinking water in sub-Saharan Africa: Issues and challenges in South-West Nigeria. Sustainable Cities and Society. 3(1), 263-272. 
INTERNATIONAL JOURNAL OF ACADEMIC RESEARCH IN BUSINESS AND SOCIAL SCIENCES

Vol. 10, No. 4, April, 2020, E-ISSN: 2222-6990 @ 2020 HRMARS

Ezeala-Adikaibe, B. A., Achor, J. U., Aneke, E., Ijoma, U., Onodugo, O. D., Orjioke, C., ... \& Ekenze, O. (2018). Pattern and determinants of self-reported enacted stigma among rural dwellers living with epilepsy attending a tertiary health facility in Enugu state Nigeria. Seizure, 56, 60-66.

Flora, S. R., Schieferecke, T. R., \& Bremenkamp, H. G. (1992). Effects of aversive noise on human self-control for positive reinforcement. The Psychological Record, 42(4), 505-517.

Fortier, M. S., Vallerand, R. J., \& Guay, F. (1995). ACademic Motivation and School Performance; Toward a Structural MOClel. Contemporary educational psychology, 20, 257-274.

Galadima, M. (2014). Rural Infrastructure Strategy for Poverty Reduction in Nigeria: Yobe IFADCBARDP Experiences. European Scientific Journal, 1(2), 23-34.

Gaudou, B. (2008). Formalizing social attitudes in modal logic (Doctoral dissertation, Université de Toulouse, Université Toulouse III-Paul Sabatier).

Ghani, Z. A. (2017). A comparative study of urban crime between Malaysia and Nigeria. Journal of Urban Management, 6(1), 19-29.

Giwa, A., Alabi, A., Yusuf, A., \& Olukan, T. (2017). A comprehensive review on biomass and solar energy for sustainable energy generation in Nigeria. Renewable and Sustainable Energy Reviews, 69, 620-641.

Hewitt, J., Ray, C., Jewitt, S., \& Clifford, M. (2018). Finance and the improved cookstove sector in East Africa; Barriers and opportunities for value-chain actors. Energy policy, 117, 127-135..

Hilson, G., Hilson, A., \& Maconachie, R. (2018). Opportunity or necessity? Conceptualizing entrepreneurship at African small-scale mines. Technological forecasting and social change, 131, 286-302.

Ikurekong, E. E., and Jacob, A. (2013). Community-environment relations and development of rural communities in Uyo, Nigeria. African Journal of Environmental Science and Technology, 7(7), 591-602.

Krejcie, R. V., \& Morgan, D. W. (1970). Determining sample size for research activities. Educational and psychological measurement, 30(3), 607-610.

Lahkar, R., \& Pingali, V. (2016). Expansion and welfare in microfinance: A screening model. Economic Modelling, 53, 1-7.

Likert, R. (1932). A Technique for the Measurement of Attitudes. Archives of Psychology, 1(40), 155.

Maslow, A. H. (1962). Lessons from the peak-experiences. Journal of humanistic psychology, 2(1), 918.

Müller-Godeffroy, E., Lehmann, H., Küster, R. M., \& Thyen, U. (2005). Quality of life and psychosocial adaptation in children and adolescents with juvenile idiopathic arthritis and reactive arthritis. Zeitschrift fur Rheumatologie, 64(3), 177-187.

Murshid, N. S., Ely, G. E. (2016). Microfinance participation and contraceptive decision-making: results from a national sample of women in Bangladesh. Public Health, 12(9), 141-147.

Nkemngu, A. P. (2015). Quality of life and tourism impacts: a community perspective. African Journal of Hospitality, Tourism and Leisure, 4(1), 1-13.

Nwanyanwu, O. J. (2011). Micro finance in Nigeria: problems and prospects. African Research Review, 5(2). 
INTERNATIONAL JOURNAL OF ACADEMIC RESEARCH IN BUSINESS AND SOCIAL SCIENCES Vol. 10, No. 4, April, 2020, E-ISSN: 2222-6990 @ 2020 HRMARS

Okoye, C. O., Taylan, O., \& Baker, D. K. (2016). Solar energy potentials in strategically located cities in Nigeria: Review, resource assessment and PV system design. Renewable and Sustainable Energy Reviews, 55, 550-566.

Okwoli, D. M., Abubakar, Y. I., \& Abubakar, I. J. (2013). Microfinance banks and rural development in Nigeria (2007-2012). International Journal of Capacity Building in Education and Management (IJCBEM), 2(1), 55-67.

Olojede, A. A., Adekunle, A. A., \& Samuel, E. A. (2013). Analysis of rural literacy as a panacea for socio-economy development of Nigeria. International Journal of Sociology and Anthropology, 5(9), 381.

Othman, M. B. (2015). Role of women in achieving shared prosperity: An impact study of Islamic microfinance in Malaysia. Procedia-Social and Behavioral Sciences, 211, 1043-1048.

Oyedepo, S. O. (2014). Towards achieving energy for sustainable development in Nigeria. Renewable and sustainable energy reviews, 34, 255-272.

Phillips, D. (2006). Quality of life: Concept, policy and practice. Routledge.

Samer, S., Majid, I., Rizal, S., Muhamad, M. R., \& Rashid, N. (2015). The impact of microfinance on poverty reduction: Empirical evidence from Malaysian perspective. Procedia-Social and Behavioral Sciences, 195, 721-728.

Sanders, I. T. (1958). Theories of Community Development. Rural Sociology, 23(1), 1.

Shaaban, M., \& Petinrin, J. O. (2014). Renewable energy potentials in Nigeria: Meeting rural energy needs. Renewable and Sustainable Energy Reviews, 29, 72-84.

Taramol, K. G. (2015). The Impact of Micro Finance on Rural Household. International Journal of Emerging Technology and Advanced Engineering, 5(4).

Tchuigoua, H. T. (2018). Which types of microfinance institutions decentralize the loan approval process?. The Quarterly Review of Economics and Finance, 67, 237-244.

Tibesigwa, B., \& Visser, M. (2016). Assessing gender inequality in food security among small-holder farm households in urban and rural South Africa. World Development, 88, 33-49.

Torres, E., \& Zeidan, R. (2016). The life-cycle of national development banks: The experience of Brazil's BNDES. The Quarterly Review of Economics and Finance, 62, 97-104.

Udochukwu, B., Akurua, I. E., Onukwube, O. I., Okoro, E. S., Obe. (2017). Towards 100\% renewable energy in Nigeria. Renewable and Sustainable Energy Reviews, 7(1), 943-953.

Ventegodt, S., Henneberg, E. W., Merrick, J., and Lindholt, J. S. (2003) Validation of two global and generic Quality of Life questionnaires for population screening: Screen QOL \& SEQOL. The Scientific World Journal, 3(1), 412-421.

Ventegodt, S., Hilden, J., and Merrick, J. (2003) Measurement of the quality of life I. A methodological framework. The Scientific World Journal, 3(1), 950-961.

Ventegodt, S., Merrick, J., and Anderson, N. J. (2003) Quality of life theory I. The IQOL theory: an integrative theory of the global quality of life concept. The Scientific World Journal, 3(1), 10301040.

Warsame, M. H., \& Ireri, E. M. (2018). Moderation effect on mobile microfinance services in Kenya: An extended UTAUT model. Journal of Behavioral and Experimental Finance, 18, 67-75.

Welsch, H. P., \& Kuhns, B. A. (2002). Community-based enterprises: propositions and cases. An Entrepreneurial Bonanza, 17-20. 
INTERNATIONAL JOURNAL OF ACADEMIC RESEARCH IN BUSINESS AND SOCIAL SCIENCES

Vol. 10, No. 4, April, 2020, E-ISSN: 2222-6990 @ 2020 HRMARS

Yimga, J. (2018). Microfinance expansion and its effects on cost efficiency. The Quarterly Review of Economics and Finance, 69, 205-216. 